REFERENCES

Adolph, E. F., and Molnar, G. W. (1946). Amer. F. Physiol., 146, 507. Benzinger, T. H. (1962). 22nd Congress of International Union of Physiological Sciences, Leiden, vol. 1, Pt. 1, p. 415 (International Congress Series, No. 47.) Amsterdam.

Burton, A. C., and Edholm, O. G. (1955). Man in a Cold Environment, p. 213. London

Carlson, L. D. (1954). Proc. Soc. exp. Biol. (N.Y.), 85, 303.

Clarke, R. S. J., Hellon, R. F., and Lind, A. R. (1958). F. Physiol. (Lond.), 143, 454.
Nielsen, M. (1938). Scand. Arch. Physiol., 79, 193.

Pugh, L. G. C. E. (1958). f. Physiol. (Lond.), 141, 233.

and Edholm, O. G. (1955). Lancet, 2, 761.

- et al. (1960). Clin. Sci., 19, 257.

- (1964). Lancet, 1, 1210.

- (1966a). Brit. med. F., 1, 123.

- (1966b). Nature (Lond.), 209, 1281.

Strømme, S., Lange Andersen, K., and Elsner, R. W. (1963). F. appl. Physiol., 18, 756.

\title{
Hodgkin's Disease*-II
}

\section{W. SMITHERS, $†$ M.D., F.R.C.P., F.R.C.S., F.F.R.}

\section{General Manifestations}

Hodgkin's disease differs from most other invasive neoplasms chiefly in its recurrent spontaneous regressions, its fever (often remitting), its varied and severe infections (frequently of the rarer and opportunistic kinds), its anergy, immunoglobulin abnormalities, anaemias, lymphoid depletion, pruritus, loss of weight (sometimes severe at the onset of the disease), its tendency to affect near relatives, and its association with certain virus diseases. It is indeed characterized by those general symptoms which are concerned with its origins as a proliferative disorder of immunologically active cells complicated by the wide destruction of lymphocyte and blood-forming tissue effected by the treatments given. The most dramatic demonstration of anergy in this disease is the acceptance of foreign skin grafts, shown in some lymphomas and notably in Hodgkin's disease by Kelly, Good, and Varco (1958) and by Green and Corso (1959), and repeated for me by my colleague, Mr. C. I. Cooling, on several of my patients (Fig. 5).

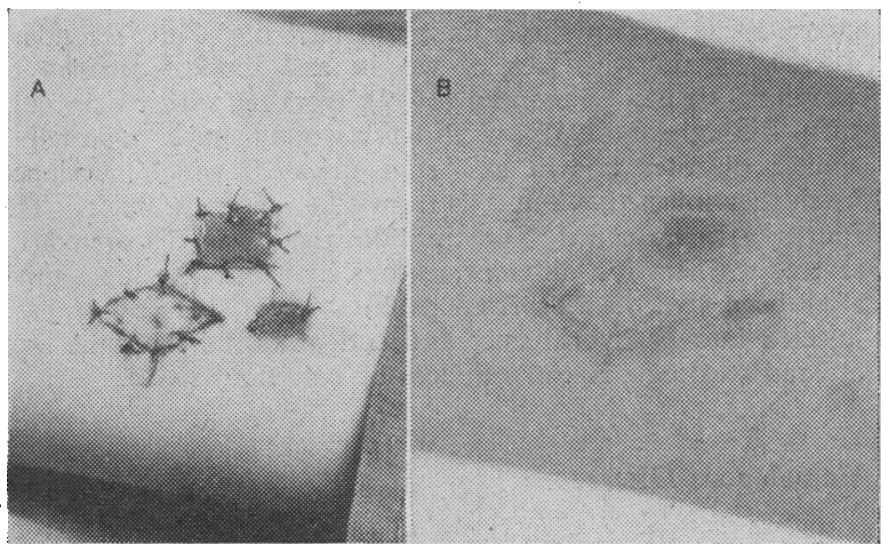

FIG. 5.-Three thicknesses of skin graft from a father to his son with Hodgkin's disease, showing no immune reaction. Grafts intact to death. A, 11 April 1960. B, 3 May 1960.

It is often difficult to pin down the beginnings of Hodgkin's disease. Previous illness may be attributed to other causes by the patient or dismissed or not inquired into by the doctor. The closer the inquiry the more frequently is a history of illness before the first node enlargement obtained and the more often is there a story to be heard of spontaneous remission, with nodes increasing and then decreasing in size. Ten patients

* Bradshaw lecture delivered at the Royal College of Physicians of London on 2 November 1966. Part I was published last week.

+ Director, Radiotherapy Department, Royal Marsden Hospital and Institute of Cancer Research: Royal Cancer Hospital, London Institute

C in our series of 350 seen during 1945-64 gave a clear-cut history of such remissions. The longest period during which remissions took place without treatment was 12 years; a node was removed and confirmation of the diagnosis obtained at the start of this long period. This patient is one of only two in our series in whom regression was noticed in lymph-node sites other than the neck (where it is easiest to detect), but she also showed spontaneous regression and return of metastases in the lungs. Some of the other patients noticed neck nodes enlarging and diminishing but tending to get larger and stay longer each time. One patient had attacks of fever and pruritus with each exacerbation. Most of these patients had one remission, and came to treatment when symptoms recurred. The regressions were repeated over one to three years in three patients, a regression lasted two years in one patient, and regressions lasted three to six months in five patients.

Fever, loss of energy, and loss of weight (sometimes severe) may occur before the lymphadenopathy is noticed. Out of 271 staged patients, 108 had developed these general symptoms by the time they were first seen. Loss of weight was severe in 32 , 16 of whom said they had lost a stone $(6.4 \mathrm{~kg}$.) or more. Of these 108 patients $45(42 \%)$ had general symptoms before they or their doctors detected any node enlargement. Seventeen of the 45 had general symptoms manifest less than six months before lymph-node enlargement was detected; in 11 patients the interval was six months to one year; in 13 the interval was one to two years; and in four more than two years. From the start some of these patients-perhaps all-had nodes involved, possibly in the mediastinum or abdomen, but nevertheless a general illness may be the first sign of the disease in $16 \%$ or more of all new cases seen. One patient felt ill for a long time; repeated examinations showed nothing abnormal, and he joined a merchant ship as doctor for a year, hoping that the change would help him to recover. He got worse, and by the end of the year had further weakness, dyspnoea, pruritus, and anaemia, with swelling of his ankles. An enlarged node was first detected and removed two years after he began to feel weak; he was dead three months later.

\section{Relation to Other Disorders}

The relation of Hodgkin's disease to certain other disorders is a fascinating study in itself, and cannot be more than touched on here. The commonest of these associated disorders is herpes zoster, the generalized form of which-indistinguishable from varicella-is to be seen most frequently in patients with lymphomas (Burgoon, Burgoon, and Baldridge, 1957 ; Williams, Diamond, Craver, and Parsons, 1959). Dayan, Morgan, HopeStone, and Boucher (1964) reported four cases of the generalized 
form of herpes zoster, two of which were associated with lymphosarcoma and two with Hodgkin's disease, in both of which the attack was fatal. We have in our series four examples of generalized herpetic dermatitis in Hodgkin's disease, one with a clear-cut herpes zoster at the same time and three without; one of these also had multiple verrucae, mentioned by Miller (1965) as occurring in Hodgkin's disease. In none of our four cases was the attack fatal.

Infectious mononucleosis is another disorder having an association with Hodgkin's disease. This self-limiting disease of lymphoreticular tissue, with characteristic clinical, anatomical, haematological, and serological changes, is suspected of a viral origin and has occasional immunological side-effects such as thrombocytopenia and hypersplenism. It has occurred shortly before or at the same time as the recognition of Hodgkin's disease in a number of patients (Massey, Lane, and Imbriglia, 1953 ; Kenis, Dustin, and Peltzer, 1958 ; Davidsohn and Lee, 1962). We have made no detailed inquiry into this matter, but in our series we have four patients in whom infectious mononucleosis was known to have preceded the detection of Hodgkin's disease.

Yet another disease of related interest is sarcoidosis, with its disordered immune mechanisms, granulomatous reactions, and tendency to mimic the lymphoreticular neoplasms. There are indeed numerous examples to be found of possible clinical leads among viral and immunological disorders.

Hodgkin's disease, then, presents a complicated picture. Tumours of lymphoreticular tissues, indeed, have something in common with tumours of the endocrine glands in that both are proliferative disorders involving general regulatory systems. Both these groups display features similar in some respects to those of other progressive tumours, while at the same time being liable to widespread disorders of regulation within their own functional spheres. The combination in the lymphomas is one of disseminating malignant tumour and disorder of the immune system. Immune disorder is not merely the result of tumour formation, for it may also be the cause. The lymphoreticular neoplasms provide further support for the view that understanding of tumour formation follows understanding of the normal regulating mechanisms in each tissue or system of the body separately and in turn. There is no short cut. Irregular growth tends to follow disturbances of normal control, to be based on functional demand, and to vary in degree according to the amount of disorder induced.

\section{Animal Experiment}

In Hodgkin's disease we have run the gamut of ideas about 1ts aetiology and nature from a specific infective organism such as the avian tubercle bacillus to a primary carcinoma arising in the thymus. The new ideas which have brought about a change in outlook have been connected with the growth of understanding of the immune system, more particularly (1) the discovery of autoimmune disease in man and homologous disease in laboratory animals, and the recognition of the resemblance of these diseases to certain aspects of Hodgkin's disease ; (2) the development of a Hodgkin's-disease-like tumour in mice surviving homologous diseases ; and possibly (3) the resemblance between Burkitt's African lymphoma and the consequences of a virus-initiated immunological injury in mice without infectious virus being present.

\section{Relation to Autoimmune Disease}

In February 1958, while preparing a lecture dealing in part with lymphomas of the thyroid and their possible association with autoimmune thyroiditis, I was increasingly struck by the similarities between some of the unexplained manifestations of
Hodgkin's disease and graft-versus-host reactions. In this Robert Knox lecture, given in May 1958 (Smithers, 1959), I put forward some reasons for supposing that homologous discase in laboratory animals and lymphoreticular neoplasia in man had much in common. I suggested that many aspects of Hodgkin's disease might be explained on the basis that it was a tumour containing immunologically competent cells able to mount a reaction against the host. In January 1959, while driving with Dr. Henry Kaplan from San Francisco to Carmel and discussing this subject, we found that we had both arrived at the same conclusion from quite different starting-points (Kaplan and Rosston, 1959b). Our common idea was that the similarities between homologous disease in animals and lymphoreticular neoplasia in man might be due to cytoimmunological reactions of lymphoid cells against the host. We decided to present this view jointly and more fully (Kaplan and Smithers, 1959).

At about the same time Dameshek and Schwartz (1959) were also considering relations between leukaemia and autoimmune disease ; they compared autoimmunization, which, once begun, is often self-perpetuating, with the abnormal cellular proliferation of leukaemia ; they remarked on antigenic stimulation to proliferation in the reticuloendothelial, lymphocytic, and plasmocytic systems, and pointed out the crucial difference between immune response growth pattern and that of other cellular proliferations in that antibody-forming cells remembered previous antigenic stimulation, and reacted even more energetically than before to subsequent demand. In 1965 Dameshek went so far as to say that " at least in some instances, autoimmunity and certain forms of leukaemia, notably of the lymphocytic variety, are fundamentally either the same disease or different expressions of the same disturbance."

This story of a new understanding developing during the last 10 years started in animals more than 40 years ago with the discovery of "parbiosis intoxication," a condition in which one animal of a pair placed in parabiosis remained well while the other lost weight and suffered a profound atrophy of lymphoid tissue. The next step was taken by Loutit and his colleagues (Barnes and Loutit, 1956 ; Ford, Hamerton, Barnes, and Loutit, 1956), who injected spleen and marrow cells into lethally irradiated mice to prevent radiation death, and discovered that certain survivors might later die of a " secondary disease," again with loss of weight and marked atrophy of lymphoid tissue. Simonsen (1957), working with chicks, and then Billingham (1958), with very young mice, reported a similar disorder known as "runt disease," which developed when they injected spleen cells from a homologous donor. The fourth variant, called "wasting disease," was discovered by several workers for different reasons at about the same time, after haemopoietic cells from parental-strain donors had been injected into $F_{1}$ hybrid mice and had produced the same type of fatal wasting disease with loss of lymphoid tissue.

\section{Homologous Disease}

There had, then, been discovered a series of immunological disorders which Trentin (1957) grouped together under the title of "homologous disease." Their common features were wasting, anaemı, and lymphoid depletion. They were all due to the reaction of foreign lymphoid cells against the host. They differed only in the reasons why the host failed to repel the invaders. Foreign immunologically competent cells which were not rejected attacked host lymphoid tissue, so that these animals lost their ability to mount a cellular immunological reaction, demonstrated by the fact that at this stage they were unable to reject skin grafts.

The similarities of these immunological disorders to Hodgkin's disease with its frequent loss of weight, progressive lymphoid depletion, and anergy seemed clear. The supposition that some of the tumour cells in Hodgkin's disease might 
become changed through irregular growth and so act as though they were "foreıgn," producing a graft-versus-host reaction which would account for previously unexplained manifestations, seemed reasonable. The interest now lay in trying to discover if-and if so, how-immunologically competent tumour cells which appeared to be of host origin might acquire foreign characteristics and whether this suspected change had any bearing on aetiology as well as on symptomatology.

Some animals with homologous disease recovered to live with a functioning immune system produced by repopulation with lymphocytes left over from the struggle (Kaplan and Rosston, 1959b). When Kaplan and I wrote our paper we pointed out at that time that no test had been made to confirm the presumed chimeric nature of these survivors from homologous disease, and that there was little information about them. It is now known that, as they recover, these animals once more reject foreign skin grafts and shed any which they may have accepted during the acute phase of their illness, but that thenceforth they can accept repeated injections of the original strain of foreign lymphoid cells. They have become capable of immunological reaction once more, and they have achieved this recovery by employing those very foreign lymphoid cells they were unable to reject and which caused all the trouble through a graftversus-host reaction in the first place. These cells may apparently acquire tolerance to host antigens, cease to mount an anti-host reaction, and start to perform their proper function on behalf of instead of against the host. These animals have become chimeras, employing a foreign cytoimmunological system on which they depend for their survival.

Kaplan and Rosston (1959a, 1959b), working on host susceptibility to homologous disease, had varied the dose of radiation they gave and the number of cells they injected, and had also augmented the host lymphoid tissue by adrenalectomy. They found their first few survivors in those recipients which had had a high radiation dose and a large number of donor cells-that is, under conditions most favourable to the invaders. Though the disease was usually fatal in these cases, they found that, where the battle had been short and sharp, circumstances might allow a takeover by the foreign cells to occur so that the host was preserved, perhaps because the time was brief during which there was no effective immunological control.

\section{Lymphoid-cell Experiments}

These lymphocyte chimeras seemed to me to be of special interest, and in $1959 \mathrm{I}$ asked one of my colleagues, Dr. J. P. M. Bensted, working in Professor Lamerton's department in our institute, to conduct some experiments for me designed to introduce a continuous or of ten repeated flow of lymphoid cells from parental strain to $F_{1}$ hybrid rats in the hope of obtaining survivors for further study. This was first attempted by thoracic duct cannulation without success, and then by transplantation of parental-strain spleens after whole-body irradiation with 200 rads, in what turned out to be the beginning of an important set of experiments. There were two survivors in the first batch of 10 animals, both of which acquired the ability to accept repeated grafts of parental-strain spleens, any one of which would normally have been sufficient to kill such an $F_{1}$ hybrid (Fig. 6). One of these two rats developed lymphoblastic leukaemia ; at necropsy the spleen graft was found to be healthy, but the host spleen and lymph nodes were greatly enlarged. Host splenic tissue was transplanted intraperitoneally into three hybrid and two parental-strain rats; all three hybrids developed leukaemia, and one of the parental-strain rats died with an enormous spleen and enlargement of the thymus while retaining a normal white cell count.

Davis, Cole, Foley, and Rosen (1963) found leukaemia in 5 out of 54 (C57L $\times$ A) $F_{1}$ hybrid mice given a single exposure of 880 rads followed by intravenous $\mathrm{C} 3 \mathrm{H}$ bone-marrow cells; they thought that the leukaemia might have been promoted by the intensive isoantigenic stimulation to which the lymphopoietic cell population of homologous chimeras is subjected.

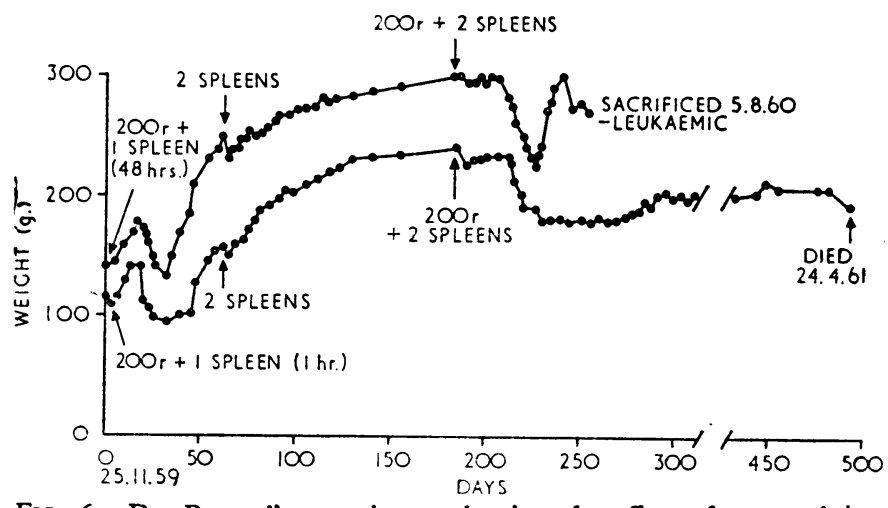

FIG. 6.-Dr. Bensted's experiment showing the effect of repeated implants of parental spleens from male August rats to two irradiated $F$ male hybrids surviving homologous disease, one of which developed leukaemia.

My own department's research group, under Dr. E. O. Field, then took up this aspect of homologous disease and again observed the development of leukaemia as a late sequel in some hybrid rats recovering from the injection of parental-strain spleen cells, this time without whole-body irradiation. In addition, Field and Gibbs (1966) confirmed that recovery from homologous disease results in a degree of resistance to rechallenge which is greater after a strong than after a weak response to the first challenge, but also-and more importantthat an obvious graft-versus-host reaction might sometimes be avoided when donor cells were given in multiple spaced fractions. They further demonstrated in several ways in their survivors, using this technique, that resistance to rechallenge was not due to immunization of the $F_{1}$ hybrid because (1) resistance was also exhibited towards rechallenge with cells from the second parental strain; (2) resistant hybrids accepted skin grafts from both parental strains ; (3) resistance could not be induced by thymic or by irradiated spleen cells; and (4) lethally irradiated thymectomized hybrids, which cannot regenerate their own lymphoid and immune systems, were yet able to develop resistance. It was found that resistance, acquired in recovery from homologous disease due to attack by lymphocytes of one parental strain, may be expressed as a means of preventing lymphocytes from either parental strains from reacting against the $F_{1}$ host.

\section{Further Studies}

Cauchi and Field (1967) have since studied the effects of cross-circulation of the blood between rats of parental and $F_{1}$ hybrid strains. They have shown that the ability to accept parental-strain lymphocytes can be passively transmitted from one hybrid in which it has been established to a normal hybrid by cross-circulating their blood for one hour. Extracorporeal irradiation of the blood during cross-circulation, with dose-rates which should be sufficient to destroy all immunologically competent cells in the blood, does not prevent the transfer of resistance to rechallenge, so it seems that a humoral factor may be involved in transmitting the ability to prevent the foreign cells reacting against the host. So far, all attempts to demonstrate resistance to rechallenge after the transfer of lymphoid cells between rats of unrelated strains have been unsuccessful. The invaders can achieve their takeover (as they do in the parent-to- $F_{1}-$ hybrid situation) when they have the Trojanhorse advantage of being undetected as foreign and the slaughter is one-sided, so long as the host does not die of immunological neglect while the fight is on. If the invaders are recognized for what they are the chance of establishing the lymphoid chimera system is very different.

Sinkovics (1962a, 1962b) published accounts of his experiments in which, starting with cells from a murine lymphoma 
grown in culture and injecting these in newborn mice, he was able to show that lymphoid neoplasia could lead back to homologous disease, since by this means he could produce either a typical runt disease or a transplant of his lymphoma.

A further and most important step was taken by Schwartz and Beldotti (1965), working again with survivors from homologous disease and using the same method as ours but in mice instead of rats. Their survivors were obtained by using 4- to 6-weeks-old $F_{1}$ hybrids and, after injection of parental spleen cells, by treating them with methotrexate (Amethopterin) to reduce mortality. They then did what we had failed to do and accumulated numbers of these survivors for long-term study, and demonstrated the development in them of Hodgkin's disease and reticulum-cell sarcoma-like tumours. Only mice which had received living parental spleen cells developed these tumours. All the tumours developed in lymphoid tissue ; liver metastases were common. While the methotrexate-treated group of mice survived longer to develop tumours, tumours also occurred in survivors not receiving the drug. Schwartz and Beldotti showed that these mice were lymphoid chimeras in which the parental cells had specific immunological tolerance for host antigens. The tumours were transplantable only to isogenic $F_{1}$ hybrid recipients and were thus, at least in their transplant characteristics, host rather than donor in origin. These were, I believe, the first Hodgkin's-disease-like tumours to be produced in laboratory animals.

\section{Virus-induced Disease}

The story has now to be approached from another direction. Professor N. F. Stanley and his colleagues in Perth, Western Australia, had been studying acute and chronic disease in mice after neonatal infection with reoviruses (Stanley, 1966 ; Stanley, Walters, Leak, and Keast, 1966). In 1963 they had drawn attention to the association of a runting syndrome with murine infection with reovirus 3-that is, they had discovered a virusinduced form of homologous disease. Their acute virus-induced disease developed, in a few cases, into a chronic immunological disorder associated with lymphoid atrophy. This work was of interest particularly in regard to the mechanism by which a virus infection might produce "foreign"-type lymphoid cells. Professor Stanley injected spleen cells intraperitoneally from a mouse so affected into isogenic newborn mice, and massive mesenteric lymph-node tumours were produced. Transmission of the tumour cells by the intraperitoneal route produced a highly reproducible syndrome rather similar to Burkitt's lymphoma. This tumour was transmitted only by intact living cells and did not contain complete infectious virus. Here, then, was an example of a chronic immunological injury, produced in the absence of infective virus but in the presence of antibody to the virus, which could also lead to lymphoid tumour development. Stanley made the suggestion that the most likely explanation of his findings was that virus-transformed (and so "foreign") cells appeared in the acute stage of the disease and then reacted against the animal's own cells in ways leading either to autoimmune disease or to neoplasia.

Rask-Nielsen (1964), who was also concerned with virusinduced leukaemia, produced an interesting disease in mice when she injected them with subcellular extracts from eight different lines of murine leukaemia. The disease was characterized by hypergammaglobulinaemia, loss of weight, haemolytic anaemia, plasma-cell infiltrations in the lungs, and amyloidosis; there was a higher incidence and more rapid course in the male. The disease appears to present some of the manifestations of lymphoreticular neoplasia produced without the injection of any viable cells. Rask-Nielsen postulated that a virus, possibly avirulent, might have transformed host cells so that they produced "foreign"-type antigens and so excited an antibody response.

The story has now taken many turnings. Homologous disease has been produced with parental spleen cells in $F_{1}$ hybrids, with the spleen cells from animals recovering from virus-induced immune disorder, and with lymphoma cells grown in tissue culture. All these types of homologous disease have been shown in different circumstances to progress to lymphoma production, mimicking lymphatic leukaemia, lymphosarcoma, reticulum-cell sarcoma, Burkitt's lymphoma, and Hodgkin's disease (Table VIII).

\begin{tabular}{c|c|c|c}
\multicolumn{2}{|c|}{ TABLE VIII.-Some Homologous Disease / Lymphoid Tumour } \\
Relationships
\end{tabular}

\section{Summary}

Many of the clinical manifestations of Hodgkin's disease are consistent with the concept that it is a progressively malignant lymphoreticular neoplasm associated with disturbances of the cytoimmunological system which it involves. Features due to proliferation, invasion, and dissemination are mingled with those due to autoimmune disorder. Controversy about its particular mode of spread lies chiefly between those who favour unifocal origin and non-random contiguous lymphatic dissemination and those (supported here) who favour occasional multifocal origin and a predominantly blood-stream spread to which I have suggested should be added specific lymph-node localization at first, followed by more general and randomized involvement later.

That Hodgkin's disease should be classified as an immunoproliferative disorder (to use Dameshek's term) seems right; that it may be initiated by immunological disturbances perhaps through the formation of "foreign"-type lymphocytes, however produced, seems quite probable ; that one way of producing such a change in these cells may be, directly or indirectly, through certain virus infections which have a preference for access through the upper respiratory tract is an interesting possibility.

I am grateful to Dr. J. S. Macdonald for the lymphograms shown in Figs. 1 and 4, and for his help in preparing Table V; to Dr. S. W. A. Kuper for Fig. 3 and for allowing me to enlarge on its possible significance; to Mr. C. I. Cooling for the skin-grafting (one case shown in Fig. 5); and to Dr. V. R. McCready for the spleen scans, one of which appears as Fig. 2. Dr. N. F. C. Gowing has reviewed many of the sections for me, and kindly allowed me to review the postmortem reports. I am indebted to Dr. J. P. M. Bensted for carrying out the interesting experiment, part of which is shown in Fig. 6, and to Dr. E. O. Field and Dr. M. N. Cauchi, of the Radiotherapy Research Unit, for a great deal of help and advice.

My thanks are also due to Mrs. D. Lambert, who spent many hours with me analysing over 400 case notes and who typed several versions of this lecture; and to Miss J. B. E. Thompson for much work in the library and for her help in preparing this text for publication.

I would also like to thank those of my colleagues on the staff of the Royal Marsden Hospital who have allowed me to review their cases so that I might present some account of all the patients with Hodgkin's disease seen at the hospital, some $60 \%$ of which were seen or treated in my unit.

(References at foot of next page) 


\title{
Heterologous Liver Perfusion in Acute Hepatic Failure
}

\author{
J. McK. WATTS,* M.B., F.R.A.C.S. ; M. C. DOUGLAS, † M.B., B.S. \\ H. A. F. DUDLEY, $\ddagger$ CH.M., F.R.C.S.ED., F.R.A.C.S. ; F. W. GURR, $\S$ M.D., M.R.A.C.P. \\ J. A. OWEN,\| M.D., PH.D., M.C.P.A., M.C.PATH.
}

Brit. med. F., 1967, 2, 341-345

When a patient with liver disease becomes comatose the outlook is grave whatever the underlying pathological process (Foulk et al., 1955 ; Katz et al., 1962 ; McDonald and de la Harpe, 1963 ; Cook and Sherlock, 1965). The usual regimen of management for such a patient (Sherlock, 1963) is designed to maintain life until recovery of hepatic function occurs and to minimize ammonia intoxication.

Recently further specific methods of treatment have been employed-cross-circulation (Burnell et al., 1965), exchange transfusion (Lee and Tink, 1958 ; Trey et al., 1966 ; Berger et al., 1966) homologous liver perfusion (Sen et al., 1966), heterologous liver perfusion (Eiseman et al., 1965 ; Eiseman, 1966), and temporary homologous or heterologous liver transplantation (Starzl et al., 1966).

(Continued from p. 340)

\section{REFERENCES}

Barnes, D. W. H., and Loutit, L. F. (1956). In Progress in Radiobiology, edited by J. S. Mitchell, B. E. Holmes, and C. L. Smith, p. 291. Edinburgh.

Bensted, J. P. M. (1960). Personal communication.

Berkman, J., Netsky, M. G., and Zimmerman, H. M. (1951). F. Neuropath. exp. Neurol., 10, 100.

Bhagwati, S. N., and McKissock, W. (1961). Brit. F. Surg., 48, 672.

Billingham, R. E. (1958). Ann. N.Y. Acad. Sci., 73, 782.

Bouroncle, B. A. (1966). Blood, 27, 544.

Brain, Lord (1963). Lancet, 1, 179 .'

Brain, Lord (1963). Lancet, 198. 1 Ibid., 2, 971.

Burgoon, C. F., jun., Burgoon, J. S., and Baldridge, G. D. (1957). 7. Amer. med. Ass., 164, 265.

Cauchi, M. N., and Field, E. O. (1967). In press.

Cook, P. L., Jelliffe, A. M., Kendall, B., and McLoughlin, M. J. (1966). Brit. F. Radiol., 39, 561 .

Dameshek, W. (1965). Quoted by W. Dameshek, Lancet, 1966, 1, 1268. and Schwartz, R. S. (1959). Blood, 14, 1151.

Davidsohn, I., and Lee, C. L. (1962). Med. Clin. N. Amer., 46, 225.

Davis, W. E., jun., Cole, L. J., Foley, W. A., and Rosen, V. J. (1963). Radiat. Res., 20, 43.

Dayan, A. D., Morgan, H. G., Hope-Stone, H. F., and Boucher, B. J. (1964). Amer. . Roentgenol., 92, 116.

Dowsett, E. G. (1966). Brit. F. Cancer, 20,16

Field, B. O., and Gibbs, J. E. (1966). Clin. exp. Immunol., 1, 195.

Ford, C. E., Hamerton, J. L. L. Barnes, D. W. H., and Loutit, J. F. (1956). Nature (Lond.), 177, 452.

Gilmore, H. K., uun., ana Zelesnick, G. (1962). Penn. med. F., 65, 1047.

Goia, I. (1935). Sang, 9, 367.

Gowans, J. L., and Knight, E. J. (1964). Proc. roy. Soc. B, 159, 257.

Green, I., and Corso, P. F. (1959). Blood, 14, 235.

Hodgkin, T. (1832). Med.-chir. Trans., 17, 68.
Hoffbrand, B. I. (1965). Brit. med. Ұ., 1, 1592.

Jackson, H., jun., and Parker, F., jun. (1947). Hodgkin's Disease and Allied Disorders, p. 3 (classification), p. 14 (familial Hodgkin's).

New York. 1948$)$ f. nat. Cancer Inst., 8, 191.

(1949). Ibid., 10, 267.

- (1950). Ibid., 11, 83.

- (1962). Radiology, 78, 553.

- and Brown, M. B. (1954). Science, 119, 439.

- and Rosston, B. H. (1959a). Transplant. Bull., 6, 107

- (1959b). Stanf. med. Bull., 17, 77.

and Smithers, D. W. (1959). Lancet, 2, 1 .

Kaufman, G. (1965). Arch. Neurol. (Chic.), 13, 555.

Kelly, W. D., Good, R. A., and Varco, R. L. (1958). Surg. Gynec.

Kenis, Y., D Dustin, P., jun., and Peltzer, T. (1958). Acta haemat. (Basel), 20, 329.

Kuper, S. W. A., and Bignall, J. R. (1964). Lancet, 1, 1412.

Law, L. W., and Potter, M. (1958). \%. nat. Cancer Inst., $20,489$.

Litvak, J., L̇eder, M. M., and Kauvar, A. J. (1964). F. Neurosurg., 21,

Ljungdahl, I., Strang, R. R., and Tovi, D. (1965). Neurochirurgia (Stuttg.), $8,113$.

Loehry, C. A. (1964). Brit. med. 7., 2, 1594.
In the past six months five patients in coma have been referred to us for consideration of heterologous liver perfusion. Three of them have undergone perfusion and one of the three has survived. The remaining two patients, both with coma supervening on chronic liver disease, recovered consciousness after correction of precipitating factors and did not require perfusion. We describe here the course of the three patients with acute hepatic failure treated by heterologous liver perfusion.

\footnotetext{
* Senior Lecturer, Department of Surgery, Monash University.

† Research Associate, Department of Surgery, Monash University. Currently Lecturer in Surgery, Monash University.

¥ Chairman, Department of Surgery, Monash University.

$\S$ Director, Dialysis Unit, Alfred Hospital, Melbourne.

|| Director, Department of Biochemistry, Alfred Hospital, Melbourne.
}

Lukes, R. J., Butler, J. J., and Hicks, E. B. (1966). Cancer (Philad.), 19

Lundin, F. E., jun., Fraumeni, J. F., jun., Lloyd, W., and Smith, E. M. (1966). F. nat. Cancer Inst., 37, 123.

Marchesi, V. T., and Gowans, J. L. (1964). Proc. roy. Soc. B, 159, 283. Marshall, A. H. E., and Wood, C. (1957). 7. Path. Bact., 73, 163.

Massey, F. C., Lane, L. L., and Imbriglia, J. E. (1953).' F. Amer. med. Ass., 151, 994.

Miles, C. P., Geller, W., and O'Neill, F. (1966). Cancer (Philad.), 19, 1103.

Miller, D. (1965). In Immunological Diseases, edited by M. Samter and H. L. Alexander, p. 372. Boston.

Miller, J. F. A. P. (1961). Lancet, 2, 748.

(1962). Proc. roy. Soc. B, 156, 415.

Peters, M. V., and Middlemiss, K. C. H. (1958). Amer. F. Roentgenol., $79,114$.

Rask-Nielsen, R. (1964). Proc. Soc. exp. Biol. (N.Y.), 116, 1154

Razis, D. V., Diamond, H. D., and Craver, L. F. (1959). Ann. intern.

Med., 51, 933 .

Ricci, N., Punturieri, E., Bosi, L., and Castoldi, G. L. (1962). Lancet, 2 564.

Richards, P., and McKissock, W. (1963). Brit. med. f., 1, 15.

Rigby, P. G., Rosenlof, R. C., Pratt, P. T., and Lemon, H. M. (1966) 7. Amer. med. Ass., 197, 25.

Rosenberg, R. A., and Kaplan, H. S. (1966). Cancer Res., 26, 1225.

Scheer, A. C. (1963). Amer. F. Roentgenol., 90, 939.

Schier, W. W. (1954). Blood, 9, 236.

Schricker, J. L., jun., and Smith, D. E. (1955). Cancer (Philad.), 8, 629

Schwartz, R. S., and Beldotti, L. (1965). Science, 149, 1511

Schwarz, G., Lee, B. J., and Nelson, J. H. (1965). Acta radiol. Diagn. 3, 138 .

Simonsen, M. (1957). Acta path. microbiol. scand., 40, 480.

Sinkovics, J. G. (1962a). F. infect. Dis., 110, 282

(1962b). Arch. ges. Virusforsch., 12, 143

Smith, C. A. (1934). F. Pediat., 4, 12

Smithers, D. W. (1956). Proc., roy. Soc. Med., 49, 103.

(1959). 7. Fac. Radiol. (Lond.), 10, 3.

Sparling, H. J., jun., and Adams, R.'D. (1946). Arch. Path., 42, 338.

- and Parker, F., jun. (1947). Medicine (Baltimore), 26, 285

Spriggs, A. I., and Boddington, M. M. (1962). Lancet, 2, 153.

Stanley, N. F. (1966). Ibid., 1, 961. I. I. (1966). Ibid., 1, 962.

and Walters, M. N.-I. (1966). Ibid., 1, 962. (N.Y.), 121, 90.

Storniello, G., and Salvati, F. (1963). Riv. Anat. pat., 24, 457

Symmers, D. (1944). Arch. intern. Med., 74, 163.

Thomson, A. D. (1955). Brit. F. Cancer, 9, 37.

(1956). Proc. roy. Soc. Med., 49, 97.

Trentin, J. J. (1957). Transplant. Bull., 4, 74

Uddströmer, M. (1934). Acta tuberc. pneumol. scand., Suppl. No. 1, $\mathrm{pp}_{.}$49, 178.

20,83 .

Wilkinson, P. C. (1964). Lancet, 1, 1301.

Williams, H. M. Diamond, H. D., Craver, L. F, and Parsons, H. (1959) Neurological Complications of Lymphomas and Leukemias, p. 134 Springfield, Illinois.

Winkelman, N. W., and Moore, M. T. (1941). Arch. Neurol. Psychiat., 45, 304 . 